\title{
English Language Use in Malaysian Government and Private Civil Engineering Workplaces
}

\author{
Noor Shahariah Saleh ${ }^{1 *}$, Siti Fatimah Murtaza ${ }^{2}$ \\ ${ }^{1}$ Centre for Language Studies, Universiti Tun Hussein Onn Malaysia, Kampus UTHM Pagoh, Hub Pendidikan Tinggi Pagoh, KM 1 , \\ Jalan Panchor, 84600 Panchor, Johor, Malaysia \\ ${ }^{2}$ Centre for Language Studies, Universiti Tun Hussein Onn Malaysia, 86400 Parit Raja, Batu Pahat, Johor, Malaysia
}

Corresponding author: Noor Shahariah Saleh, E-mail: shahariah@uthm.edu.my

\begin{abstract}
ARTICLE INFO
Article history

Received: June 13, 2018

Accepted: June 29, 2018

Published: July 31, 2018

Volume: 6 Issue: 3

Conflicts of interest: None

Funding: None

ABSTRACT

Employers in the engineering sector require certain standard of English proficiency among their employees as the language is widely used for numerous job scopes. In order to understand the current demand of the civil engineering industry on the use of the English language in the workplace, this study was conducted on 20 undergraduates of the Civil and Environmental Engineering Faculty, Universiti Tun Hussein Onn Malaysia who undertook the industrial training. Based on focus group discussions, the participants learned and shared significant use of English language through their industrial training experience. The findings of the study highlighted the activities that were conducted in English for speaking, listening, reading and writing including the language skills. In addition, the amount of time spent on each activity in English was also identified in understanding the importance of English language in the civil engineering sector. The findings of the study are vital in making informed decisions for the design and development of appropriate English language courses for present and future civil engineering students.
\end{abstract}

Key words: Language Use, Language Skills, Needs Analysis, Workplace Communication, Civil Engineering Workplace

\section{BACKGROUND}

The issue of unemployment among graduates has been raised by the Ministry of Higher Education. The ministry points out that this problem stems from the lack of multiple skills and language competency (The Star, April 12, 2011). A large number of future graduate employees with excellent performance are unable to secure jobs due to their inability to demonstrate high proficiency in English. Like any other occupations, the engineering professions are not exempted from acquiring English language competency. Having high proficiency in English is considered an important asset in the context of the global economy.

Surveys show that common problems in communication during interviews among graduates include poor speaking skills, inability to comprehend questions, and lack of interaction skills (Alias, Sidhu, \& Chan, 2013). This indicates the important role of communication skills to qualify individuals to be professional engineers. Engineering professionals who take the initiative to improve their communication skills will have the opportunity to advance their career globally. Mastering communication skills in English enables engineers to interact effectively when dealing with the representatives from the same or different organization (Kakepoto, Said, Hadina Habil, Umrani, \& Memon, 2013).
Like any other professionals, engineers are also required to be proficient in English. Unfortunately, many young engineers are found to be lacking the adequate skills in expressing their thoughts and feelings in not only verbal but also written communication. Due to this matter, a great number of employers have conveyed their discontentment with the capability of future engineers in communication (Tong, 2003, as cited in Yasin, Wan, Mukhtar, Ghani, \& Rashid, 2010). Clement and Murugel (2015) highlight the need to have the ability to communicate effectively among engineering graduates in tasks such as attending interviews, working collaboratively with others, and making telephone conversation. Being proficient and competent in English then not only helps future engineers in dealing with work, but also helps them to break the cultural and international boundaries to become world renowned engineers.

The concern over engineering graduates' proficiency has led most of the recent studies to centre on exploring the linguistic and language use in the engineering education setting especially language programmes for engineering students (Gözüyeşil, 2014; Noori \& Mazdayasna, 2014; Sanmugam, 2013; Tinh, 2015). However, it is identified that the workplace setting was excluded from these studies. The target needs in the workplace deserves further consideration in order to provide a clearer picture of the authentic use and 
needs of English language. Needs analysis allows more meaningful information to be addressed and used for the development and improvement of the curriculum. Besides, past studies on language needs and use at engineering workplace were more gravitated towards other fields of engineering like the areas of semiconductor manufacturing (Spence \& Liu, 2013), computer engineering (Rajprasit \& Hemchua, 2015), chemical and biochemical engineering (Kassim \& Ali, 2010), and general engineering (Rahprasit et al., 2014). This excessive attention has caused a gap in ESP studies in that current information concerning the needs and use of English language in the civil engineering and construction management workplace and to be less discovered especially in Malaysian context. Additionally, there appears to be deficient in studies within the perspective of civil engineering workplace, predominantly in terms of how language is used and what language skills or competencies are needed. This enables learners to benefit from it in terms of their preparation before they involve in the real job (Kaewpet, 2009). Therefore, this paper seeks to investigate the use of English in the Malaysian Civil Engineering project and construction management context. It aims to achieve the following objectives:

1. To determine the English language skills used by industrial trainees at the civil engineering project and construction management workplace

2. To identify the specific tasks, activities, and events which necessitate English language skills

The findings of the study are beneficial for future civil engineers or graduates in their career development. The findings of this study also provide curriculum designers with information that can be used to design and improve English language courses for civil engineering and construction management students. Such findings can be used by the higher education institutions to prepare students for the actual workplace.

\section{LITERATURE REVIEW}

\section{English Use at Work}

English is a vital language in bridging employees and employers' communication in the Malaysian workplace. Being a multiracial country with international and global companies venturing into Malaysia's economy, knowing English allows for effective communication as Bahasa Malaysia is not used very much. Gill (2002) and Bhar et al. (2013) point out that at English plays an important role in attaining Malaysia' status to be in line with other countries in terms of economic development. English not only is an essential international language, it also serves as a medium of communication inside and outside an organization in Malaysian setting (Moslehifar \& Ibrahim, 2012). The ability to communicate in English effectively and confidently in numerous situations, inside or outside and organization permits active communication and common understanding between parties. Therefore, not only companies but Malaysia's economic growth also benefits from the effective use of English for business communication.
Insufficient information related to the use of English at the workplace has become an issue among future graduates. The industry is rather vague about which English language skills should be focused on in preparing the undergraduates to achieve commendable proficiency in English. An investigation was done by Talif and Noor (2009) on the situation of English language and competencies required by both employers and employees in communicating at the workplace. The study found that English has a greater importance in use as compared to Bahasa Malaysia. Meanwhile, the ability to speak in English was exposed as the most demanded skill in the workplace. The significant position of English in the Malaysian workplace is further corroborated by Mohd Said and Darus (2011). They examined the degree to which English was implemented in written documents. The findings revealed that there was an extensive use of English among Malaysian bank managers internally and externally but often with problems in preparing letters, minutes of meeting, memos and proposals in English. In addition, Sarudin et al. (2013) study supports the stand that English is more important that other languages at the Malaysian workplace. There appears to be a big gap between the readiness of graduates and needs of the employers with regard to employees' English competency needs. Speaking and writing are the only skills assessed during employment. Hence, English is proven to be crucial in workplace settings and identifying the explicit use of the language skills in a specific area like civil engineering assists not only the future employees but also employers to set a standard competency for the workers to adhere.

\section{Analysing Workplace Needs}

Needs analysis is a process which includes the collection of information (Zamanian \& Anari, 2014). The information usually focuses on understanding a learner of a particular language and the task usage in communication in developing a syllabus (Qasemi \& Ibrahim, 2015). Needs analysis also involves the elements to be considered and the procedure in carrying out a course conducted by the educators and the developers of the course (Prachanant, 2012). It is crucial to treat needs analysis as a constant activity as learning in higher education is correlated to the working world revolution. This facilitates the proprietors, instructors, administration, and learners to benefit from the information gathered.

Need analysis, as the knowledge and skill indicator, becomes a means of collecting current information about the learners and setting future goals. Besides, it offers the insights to improve the performance and enhance the comprehension of the language of learners. In Malaysia, needs analysis is applied in various fields. There are many studies done to revise and improve the existing curriculum in meeting the academic and sectors' demand. A study by Rahman (2012) scrutinized English language needs in computer science discipline. The researcher identified that the reading skills are required by the learners. Half of the learners rated their reading skills as average and highly necessary for them because they needed to be able to read texts or reference books, technical journal articles, research reports, magazine 
articles, newspaper articles, memos and short notes effectively. The study found that skimming and scanning were the important skills in reading and to advance the skills, the mastery of technical vocabulary was needed.

Implementing target situation needs analysis, Sanmugam (2013) unveiled the polytechnic engineering students' linguistics needs mainly in three majors which were mechanical engineering, civil engineering, and electrical engineering. Listening was identified as the dominant skill in English despite the fact that the language had a great importance in the engineering field. Learners were found lacked in several skills like reading technical texts, oral presentation skills, and listening-to-presentation skills and they wanted to acquire specific skills in English which could help their studies in the engineering programme.

In the engineering workplace, some studies have contributed in giving some insights about English language use and skills. Nordin (2013) investigated on English language skills, explicitly technical communication, among graduates of electrical and electronics engineering in working industries. It was found that half of the time at the workplace was spent for working in group and written communication. Competency in technical communication was viewed as an important criterion for engineering job advancement, but it had no connection with salary increment. Meanwhile, Spence and Liu's study (2013) is an important reference to the present research which discovered events that required the use of English among the process integration engineers (PIES) in Taiwan. Distribution of online questionnaire, group interview with 11 engineers, observation on the PI engineers in daily working circumstances, and interview with a selected customer let to the findings of some similarities of English communicative events faced by the PI engineers with those from other nations in Asia-Pacific. The findings pointed out that the highest frequency on writing and reading events are like reports, memos, and emails while oral events included presentations, teleconferences, and meetings. The increase of English needs was also found to take place simultaneously with the growth of the engineers' profession.

In the context of multinational engineering companies, the study by Kassim and Ali (2010) is significant in providing some insights into the latest information and communication skills needed. As shown in questionnaire survey findings, it was implied that consideration should be given to oral compared to written communication skills. Additionally, teleconferencing, networking for contact and advice, and delivering new thoughts and strategies were estimated to be essential in the engineering settings. The eloquence in English language paid higher prospect for engineers' development in the international sectors. It was concluded that attention should be made in integrating realistic workplace situations in English modules. Another study demonstrated the needs of communication in engineering was done by Kaewpet (2009). It re-examined the requirements of communication of civil engineering in Thai setting. A profile of the communicative needs was expanded from 18 to 37 items based on Munby's (1978) sociolinguistics model. The interviews led to the emergence of four main communicative events in the 'Technical English 1' course which were discussing everyday tasks and duties, reading textbooks, reading manuals, and writing daily or periodic reports. This study gives beneficial insight into how to apply the latest communicative events in language activities in class. Specifically, the study also serves as a basis for the current study which aims to identify the language needs at the civil engineering workplace.

\section{METHODS}

The study aimed at identifying application of English in Civil Engineering. Taking into consideration Long's (2005) claim that focus group discussions enable clear message transmission, the researchers opted to implement the method to better understand the language use and skills in civil engineering workplace through the trainee participants' experience. The questions to be discussed among the participants were divided into two themes: (1) language skills used by civil engineering trainees during the industrial training, and (2) language used according to reading, writing, listening and speaking. In order to support the findings from the focus group discussions, a professional communication checklist was prepared. The checklist provided the time distribution for communicative events for all the macro skills applied in the civil engineering and construction management workplace. As discussed in the previous section, there was insufficient information regarding the language use and skills particularly in civil engineering field in Malaysia, and therefore, the existing checklist could not be entirely embraced for this study. It was decided that the elements of communicative events should be considered from Kaewpet (2009) as it shares the same domain of engineering.

\section{Participants}

The participants were 20 students from the Faculty of Civil and Environmental Engineering of Tun Hussein Onn Malaysia University who enrolled in the fourth year of study. It was recognised that 15 of them had the industrial training at private companies and the remaining five at the government sectors. Two criteria were set for selecting this type of sample; 1) the students should still undergo their industrial training when they were approached and 2) the students should have completed their English courses.

The research consent was obtained from the participants, and the administration of Civil Engineering and Environment Faculty was made known about the research. To identify the students who were still in the process of completing their industrial practice and have completed English courses, a list of names taken from the faculty administration was referred to. The selection of students was based on the prior backgrounds, built from joining industrial practice and attending English classes, which could help them to make sense of the questions asked during the focus-group discussion related to English Language learned in classroom and used at workplace. 


\section{Instruments and Procedures}

This study implemented a focus group protocol and professional communication checklist adapted from Cheng's (2008). Since the study attempts to identify English language use and needs as well as the factors that influenced the use, the instruments were framed based on Kaewpet's (2009) list of communicative events. The topic and aim of the discussion were made known to the participants before the session starts. The maximum involvement of seven individuals in a group allowed each participant to recall and view their own experience and needs. Meanwhile, a copy of professional communication checklist was given through emails three weeks before the participants ended their practical training. The briefings were made via telephone to all the participants explaining the purpose of using the checklist and how to complete it. The completed checklist was either emailed or brought during the discussions.

\section{Data Analysis}

The conversation during the focus group discussion was transcribed. The data analysis of the discussion was based on the thematic analysis by Braun and Clarke (2006). In the meantime, descriptive analysis was applied in analysing the professional communication checklist. This analysis required the researchers to analyse the data manually using Microsoft Excel. The trends of the findings were summarised through the descriptive statistics. Each of the time allocated for a participant in a week were totalled up before transferred into Excel. The data later were calculated based on central tendency. The value from the data was expressed by scoring the mean to get the distribution of time allocation for a week by each participant.

\section{FINDINGS AND DISCUSSION}

\section{English Language Skills Needed in the Workplace}

The analysis of the focus group discussions has shown that speaking was the most required English language skill in the companies where companies where the participants attended their industrial training. The second highest was reading skill, followed by writing skill. It was informed that listening skill appeared to be the least required skill among all in communication.

Further discussions made by the participants contributed to the explanations on why speaking skill appeared to be the major skill needed in the workplace. Firstly, they experienced of using the skills of speaking in communication when completing the task within the companies during the industrial training. Not only that, what made the speaking skill to be important was when the task given related to external work which required the participants to use English as the medium to convey the message. This is supported by one of the participants in the excerpt of his statement.

\section{Excerpt 1}

Most of all it is speaking skill that I use English especially for outside work.

(Student 4, focus group 1)
Most job scopes necessitated the participants to communicate with the associates in the companies especially during discussions. In the session conducted, Student 8 expressed the same view on the use of English when transferring information among colleagues. Thus, making the speaking skill to be crucial in helping the participants in the training.

Excerpt 2

I think the major skill needed by the company is speaking because when we work, we need to discuss with the staff and face them and speak with them.

(Student 8, focus group 2)

Speaking skill was also viewed as a highly required skill due to its importance of use in dealing with the external stakeholders like clients and consultants. Good delivery was seen as an important element in conveying information. This situation was explained by Student 8 in the Excerpt 3 below.

Excerpt 3

Based on my experience, I think the most important skill in the company is speaking and communicating. This is because we need to entertain the clients, consultant and others so we need to communicate in English to have good understanding.

(Student 8, focus group 2)

From the excerpt above, the skill of speaking was perceived as a highly required skill that would enable the individuals to better engage in the discussions and comprehend the messages from the other interlocutors. The personnel included those representatives from other companies. Student 12 agreed that even though English did not always become the medium of communication in the company, the speaking skill was still important in order to interact better with the corporate from other companies.

Excerpt 4

As for speaking, I usually use to speak to the subcontractors. Since my company is a local company, so we don't use English much to each other but when the contractors come we switch to English most of the time.

(Student 12, focus group 2)

When the participants were asked about their perception on the importance of English language skills they provided the answers from the range of very important to moderately important. The Table 1 below represents the responses recorded.

Table 1 The Responses on the Importance of English Language Skills

The multiracial demography in a company was the main reason for the use of English at the workplace. Using English was highly helpful and very crucial in bridging the gap between the individuals not only inside but also outside of the company regardless of their language proficiency. Besides,

Table 1: The responses on the importance of english language skills

\begin{tabular}{lc}
\hline Answers (N=81) & $\mathbf{2 0}$ (f) \\
\hline Very important & 9 \\
Important & 5 \\
Moderately important & 6 \\
\hline
\end{tabular}


language frequently became a wall in communication in the companies. Because of the dissimilarity of first language, it was explained that English was chosen to be the substitute to enable an effective communication.

This study indicated the same result as the one conducted by Talif and Noor (2009) regarding the relationship between language needs at workplace and learning which highlighted on speaking skill. It is also in accordance with Kassim and Ali's (2010) research in terms of the importance of speaking skill. As the researchers found that oral communication skills which are speaking and listening skills required more emphasis, this study illustrates that speaking and reading skills needed to be focused on in civil engineering workplace in Malaysia. This finding is not in tandem with the results shown in Kaewpet (2009) which reading and writing skills were identified as the most essential language skills in civil engineering field in Thai context. However, it is hard to tell if speaking skill was the actual skill needed in the workplace. This was because students were not fully exposed to the real working world when they performed the tasks given during the internship. Only about a few months were spent in the sector before returning to the university. The internship was only a preliminary programme for the participants to get a picture of the actual working atmosphere. Therefore, there was a probability that companies only provided them with simpler and less risky tasks to avoid the risk of loss in terms of profit and rapport, as well as provide authentic verbal communication for more real interactions for them to engage in, thus allowing learning to take place.

\section{English in Workplace Communication}

English was used in spoken communication when attending meetings, seminars or conferences, conversing about daily tasks or duties, as well as having verbal presentations and discussions about daily life situations. The highest allocation of time was given to attending meetings, seminars, and conferences (118.5 minutes) which indicated that English was important in speaking. Based on the professional checklist, trainees spent up to two hours when attending meetings. In the meantime, seminars and conferences could take the whole working hours for a few days of the employees' time. A long period of time was spent for seminars, meetings, and conferences. Several trainees were scheduled to attend several meetings and seminars thus making the participations contributed to high accumulation of time.

Even though the participants were not involved actively in meetings, they were still asked to join the meetings like the rest of the workers. Excerpt 5 below explains the experience of Student 10 when attending meetings.

\section{Excerpt 5}

We used English in meetings. For me I listened to English meeting.

(Student 10, focus group 2)

The student generally stated that English was used in the meetings. There was no indication that other languages were used during the activity. Student 20 also experienced the same thing. She claimed that:

\section{Excerpt 6}

For me, I think we used English when we had meetings with clients and consultants, and when attended site meeting with consultants.

(Student 20, focus group 3)

It was also mentioned that speaking in English enabled a better comprehension in knowing the desire of the clients. This can be proven through one of the statements made by the participant in Excerpt 7.

\section{Excerpt 7}

I used English when communicating with the customers. Using English when dealing with the customers enabled more understanding of what they want.

(Student 17, focus group 3)

Meanwhile, when talking about daily tasks, English was important to the participants and the team in the company in liaising with the contractors to check the quality and performance of the product used in the project and obtaining information. One of the participants indicated that the trainee was given the opportunity to involve in an activity which required her to use English in the speaking event, which was talking about daily tasks and duties.

Excerpt 8

We used English in testing and conditioning. We spoke to the contractor about the product. Basically it is about the information.

(Student 12, focus group 2)

This was supported by the checklist in which the report writing activities had to be carried out every week to inform the routines in the company and the finding is consistent with the communicative event identified by Kaewpet (2009). Besides, Moslehifar and Ibrahim (2012) emphasized that tasks related work is a normal subject to be discussed among engineering professionals as it is a part of planning, carrying out, and managing projects. With regard to the findings, it happened anywhere and anytime in the settings in the existence of the participants. The activity was also performed by the employees from different levels of positions in the companies. Kaewpet (2009) pointed out that interlocution associated to everyday errands and responsibilities are done in the critical ambience like offices and sites with both formal and informal modes. Thus, as discovered from this study, it made the recurrences to be high.

Reading in English was used by the participants when dealing with project- and office-related documents. Interestingly, 12 out of 20 participants claimed that all the reading documents were written in English. Furthermore, there were also other English reading materials which were not mentioned as related to work which require English reading skills to be implemented. A participant believed that, "More English reading materials and documents related to the office (work) were in English compared to Malay". Reading was crucial in providing the participants the information about the latest projects they were involved. Most of the tasks were foreign to them that only by reading the references from the office and project documents could help the trainees to gain more insights into the matters regarding the projects. As an example, a participant shared that reading 
skill was employed recurrently during the internship. It was important for her to apply reading skills to gain information about the latest projects which was the MRT project. The project was alien to her that reading the office and project documents was the only way to expand her knowledge into the matters regarding the project.

\section{Excerpt 9}

In my internship reading skills were the skills that I used often. This is because we need a lot of reading in understanding the MRT project. As for me, the project was a new thing for me. So to handle documents and things related I used reading skills and made reference of the office and project documents.

(Student 14, focus group 2)

Despite the fact that the participants agreed that reading those documents to be the most important activity, the allocation of time per week for using computer programmes, reading Internet English resources and reading design drawings appeared to be higher. This showed that even the participants did not experience the three activities regularly in a week, the time needed to complete those tasks were longer. The complexity of the tasks and skills acquired by the participants should be considered when completing the activities.

In addition, three writing activities were also identified, namely preparing documents for projects, completing reports periodically or daily, and writing meeting minutes. Preparing documents for projects, however, did not require the participants to start from scratch. It was explained that the process technically began by looking at the existing documents and later replicating the old version of the documents. This can be seen in the example below:

Excerpt 10

... I would start writing in English for the new tender following the old reference. I just improved the English used in the old one especially the words and scope of work that needed to be changed.

(Student 4, focus group 1)

Writing documents is a part from the task required to be performed by the engineering employees. These include writing BQ and claim, which are related to project documents. One of the participants claimed that most companies used English not only in speaking but also writing. The engineering workers were required to participate in the activity of writing documents. The statement is as follows:

Excerpt 11:

As for me, I think I think I need to master speaking and writing skills in English. This is because in most companies [related to civil engineering] they [engineering employees] have to write documents such as for claiming, $B Q$, and they turn to English to write all the documents.

(Student 3, focus group 1)

Besides, writing periodic reports was an activity that occurred regularly at the workplace and interconnected with the other events such as meetings. The report writing activities usually had to be carried out every week to inform the routines that the participants did in the company and to record the meetings that the participants attended. Even though the participants did not stress on the importance of using emails during the discussions, the amount of time spent for it was still high. The time allocated for writing project documents surpassed that for emails with 198 minutes and 141 minutes.

The discussion led to the findings that listening activities revolved around receiving spoken instructions and attending seminars, meetings, and conferences. Receiving spoken instructions always occurred during the industrial training and recorded the highest time distribution (70.5 minutes per week) as participants required some guides in manoeuvring the tasks given.

\section{Excerpt 12}

We listened in big group discussions, meetings and when I met my supervisor for a discussion.

(Student 14, focus group 3)

As exemplified in the excerpt above, Student 14 had the chance to attend the discussions and meetings held by the company at which she experienced her training. When she declared that there was a discussion made between her and the supervisor, it brought the idea that the activity included receiving spoken instructions as well. Another three participants experienced the similar occasion. Moreover, there were opportunities given by most of the companies to the participants to experience attending seminars, meetings and conferences. This was also important to enable participants to add more knowledge in the workplace.

\section{CONCLUSION}

This study aimed at investigating English language use in civil engineering project and construction management from the perspective of trainees. It was found that speaking was the most crucial skill in the civil engineering workplace. Overall the findings revealed that English language skills were perceived as important not only for industrial training but in real working field. Attending meetings, seminars or conferences, conversing about daily tasks or duties, as well as having verbal presentations and discussions about daily life situations where the activities highlighted in verbal communication. Meanwhile, project and office based documents involved in reading communicative events. Preparing documents for projects, completing reports periodically or daily, and writing meeting minutes were recognised to be the activities related to English writing skills used in the workplace. From the focus group discussions, the findings illustrated that the activities related to listening were receiving spoken instructions and attending seminars, meetings, and conferences.

The discrepancies between time allocations of activities with communicative events in the workplace open up an opportunity for future researchers to expend the sample size and vary the data collection method in getting more reliable findings. Besides, the longer time is needed for the participants to record information regarding the activities conducted during the industrial training. It is suggested that the participants to start recording the communicative events from the very beginning of the training programmes. This enables more holistic and detailed information to be gathered.

The study is a useful reference for future civil engineers. Since it is more competitive in securing a job in the 
local and international market, mastering the English skills highlighted in this study prepares the undergraduates for the workplace. Omar et al. (2012) agreed that the unemployment among graduates can be reduced by equipping candidates with the required skills in the selected field. Furthermore, the findings of this study provide curriculum designers with information that could be used to design and advance English courses for civil engineering and construction management students. Thus, this would enable higher education institutions, English instructors, and lecturers to prepare suitable content in the class that suits the actual workplace.

\section{REFERENCES}

Alias, M., Sidhu, G. K., \& Chan, Y. F. (2013). Unemployed graduates' perceptions on their general communicationskills at job interviews. Procedia - Social and Behavioral Sciences, 90, $324-333$.

Azizan, H., \& Lee, Y.M. (2011, April 12). Minding our language. The Star Online. Retrieved November 5, 2016, from http://www.thestar.com.my/travel/malaysia/2011/04/12/minding-our-language.

Bhar, S. K., \& Bakar, N. A. A. (2013). Language barriers: Feedback from the IT industry. Journal of Technical Education and Training, 4(2).

Braun, V. \& Clarke V. (2006). Using thematic analysis in psychology. Qualitative Research in Psychology 3, 77-101.

Cheng, W., \& Mok, E. (2008). Discourse processes and products: Land surveyors in Hong Kong. English for Specific Purposes, 27(1), 57-73.

Clement, A. \& Murugel, T. (2015). English for employability: A case study of the English language training needs analysis for engineering students in India. English Language Teaching, 8(2), 116-125.

Gill, S. K. (2002). International communication: English language challenges for Malaysia. Serdang: Universiti Putra Malaysia Press.

Gözüyeşil, E. (2014). An analysis of engineering students' English language needs. Procedia-Social and Behavioral Science, 116,4182-4186.

Kaewpet, C. (2009). Communication needs of Thai civil engineering students. English for Specific Purposes, 28, 266-278.

Kakepoto, I., Said, H., Hadina Habil, Umrani, A. I., \&Memon, I. A. (2013). Workplace communication: Oral communicative competence of engineers in engineering workplace of Pakistan. Information and Knowledge Management, 3(2), 131-138.

Kassim, H., \& Ali, F. (2010). English communicative events and skills needed at the workplace. Feedback from the

industry. English for Specific Purposes, 29, 168- 182.

Long, M. H. (2005). Second Language Needs Analysis. Cambridge: Cambridge University Press.

Mohd Said, N. E., \& Darus, S. (2011). Workplace writing in English: insights from Malaysian bank managers. GEMA: Online Journal of Language Studies, 11(3), 219-233.
Moslehifar, M. A., \& Ibrahim, N. A. (2012). English language oral communication needs at the workplace: Feedback from human resource development (HRD) trainees. Procedia- Social and Behavioral Science, 66,529-536.

Munby, J. (1978). Communicative syllabus design: A sociolinguistic model for defining the content of purpose-specific language programmes. Cambridge: Cambridge University Press.

Noori, M. \& Mazdayasna, G. (2014). A triangulated study of target situation needs of Iranian undergraduate students of English language and literature. Procedia-Social and Behavioral Sciences, 98, 1374-1379.

Nordin, R. (2013). Technical communication skills among recent electrical and Electronics engineering graduates in job industries. Global Journal of Engineering Education, 15(3), 160-164.

Omar, N. H., Abdul Manaf, A., Kassim, A. C., \& Abd. Aziz, K. (2012). Graduates' employability skills based on

current job demand through electronic advertisement. Asian Social Science, 8(9), 103-110.

Prachanant, N. (2012). Needs analysis on English language use in tourism industry. Procedia-Social and Behavioral Sciences, 66, 117-125.

Qasemi, A. S. (2015). An Investigation of English Language Needs of Engineering Undergraduates at Jawzjan University.

Rahman, M. M. (2012). The English language needs of computer science undergraduate students at Putra University, Malaysia: Focus on reading skills. English for Specific Purposes World, 12(34), 1-25.

Rajprasit, K., Pratoomrat, P., Wang, T., Kulsiri, S., \& Hemchua, S (2014). Use of English language prior to and during employment: Experiences and needs of Thai novice engineers. Global Journal of Engineering Education, 16 (1), 27- 33.

Rajprasit, K., \& Hemchua, S. (2015). The English language and communication in the international workplace: An

examination of Thai computer engineering professionals. The Southeast Asian Journal of English Language Studies, 21(3), 109-124.

Saruddin, I., Mohd Noor, Z., Zubairi, A. M., Tunku Ahmad, T. B., \& Nordin, M. S. (2013). Needs assessment of workplace English and Malaysian graduates' English language competency. World Applied Sciences Journal $21,88-94$.

Sanmugam, S. T. (2013). Target situation needs analysis: Exploring the linguistic needs of polytechnic engineering students across three majors. English for Specific Purposes World, 14(39), 1-9.

Spence, P., \& Liu, G. Z. (2013). Engineering English and the high-tech industry: A case study of an English needs analysis of process integration engineers at a semiconductor manufacturing company in Taiwan. English for Specific Purposes, 32, 97-109.

Talif, R., \& Noor, R. (2009). Connecting language needs in the workplace to the learning of English at tertiary level. Pertanika Journal of Social Sciences \& Humanities, 17(2), 65-77. 
Tinh, L. C. (2015). Needs analysis of English for mechanical engineering students in the Vietnamese context. $6^{\text {th }}$ International Conference on Responding to Challenges of Teaching English for Communication, SEAMO Regional Training Centre.

Yasin, A. Y., Wan, M. H., Mukhtar, A., Ghani, A. I., \& Rashid, F. (2010). The English Proficiency of Civil
Engineering Students at a Malaysia Polytechnic. Asian Social Science, 6(6), 161-170.

Zanmanian, M., \& Anari, N. N. (2014). Relationship between subjective and objective needs analysis of ESP students at M.A. level. International Journal of English and Education, 3(2). 288- 312. 